\title{
Clear cell meningioma in a child: Case report and systematic literature review
}

\author{
Meningioma de células claras en una niña: revisión sistemática de \\ la literatura y reporte de caso
}

\author{
Pedro Henrique Simm Pires de Aguiar BA', Roberto Alexandre Dezena MD, MSc, PhD', Giovanna \\ Galafassi BA $^{2}$, Fernando Furtado Santos BA ${ }^{2}$, Lívia Marques Marangoni BA ${ }^{1}$, Marcos Vinicius Calfat \\ Maldaun MD, PhD $^{4}$, Paulo Henrique Pires de Aguiar MD, PhD ${ }^{4,5,6}$
}

\author{
${ }^{1}$ Graduation Medicine at School of Medicine of Pontifical Catholic University of Sorocaba. São Paulo, Brazil. \\ ${ }^{2}$ Graduation Medicine at School of Medicine of ABC, Santo André. São Paulo, Brazil. \\ ${ }^{3}$ Division of Neurosurgery of Federal University of Uberaba (UFTM), Uberaba. Minas Gerais, Brazil. \\ ${ }^{4}$ Division of Neurosurgery of Santa Paula Hospital. São Paulo, Brazil. \\ ${ }^{5}$ Division of Neurology of Pontifical University of Sorocaba. São Paulo, Brazil. \\ ${ }^{6}$ Researcher of ABC Medical School. Santo André, Brazil.
}

\section{Resumen}

\begin{abstract}
Antecedentes: El meningioma de células claras (MCC) consiste en una variante poco común de meningiomas que generalmente ocurren en niños. Este tumor poco común se comporta de manera agresiva y las tasas de recurrencia son altas. Las manifestaciones clínicas son atípicas y el tratamiento generalmente implica cirugía. Métodos y Objetivos: Realizamos una revisión sistemática con el fin de definir las características más comunes de este raro tumor. Pubmed y LILACS fueron las bases de datos utilizadas para la búsqueda bibliográfica. Se incluyeron 17 estudios que cumplieron con nuestros criterios. Para avanzar en nuestra investigación, incluimos el caso clínico de una niña de 3 años con CCM operada en nuestro servicio. Resultados: Los MCC fueron más frecuentes en la población pediátrica que en la adulta, especialmente en el sexo femenino. La resección macroscópica del tumor y el índice MIB- $1 \leq 3$ fueron los parámetros relacionados con una menor tasa de recurrencia. La resección subtotal del tumor fue seguida de radioterapia en la mayoría de los casos de adultos. La mutación SMARCE-1 se pudo encontrar en varios pacientes.

Conclusión: Los MCC son meningiomas raros que ocurren especialmente en niños. La agresividad y las altas tasas de recurrencia dificultan el manejo de esta enfermedad. Aún queda mucho por discutir sobre estos tumores raros, lo que exige más investigación.
\end{abstract}

Palabras clave: Tumor cerebral, meningioma de células claras, meningioma.

\section{Abstract}

Background: Clear Cell Meningioma (CCM) consists in a rare variant of meningiomas that generally occur in children. This uncommon tumor behaves aggressively and recurrence rates are high. Clinical manifestations are atypical, and the treatment generally involves surgery. Methods and Goals: We performed a systematic review in order to define the most common characteristics of this rare tumor. Pubmed and Lilacs were the databases used for the literature search. We included 17 studies that met our criteria. To further our research, we included the case report of a 3-year-old female child with CCM operated in our service.

Results: CCMs were more frequent in the pediatric population than in adults, especially in females. Gross tumor resection and MIB-1 index $\leq 3$ were the parameters related to a smaller recurrence rate. Subtotal tumor resection was followed by radiotherapy in most adult cases. SMARCE-1 mutation could be found in several patients. Conclusion: CCMs are rare 
meningiomas that occur especially in children. The aggressiveness and high recurrence rates difficult the management of this disease. There is still a lot to be discussed about these rare tumors, demanding further research.

Key words: Brain tumor, clear cell meningioma, meningioma.

\section{Introduction}

Cranial meningiomas are rarely found in children and teenagers. Cushing and Eisenhardt described an incidence in children of $1.9 \%$ among 313 patients with meningiomas in their famous 1938 monograph ${ }^{10}$. A contemporary surgical series documented an incidence of $1.08 \%$ among children and teenagers operated over a 15-year period (1985 - 2000) ${ }^{19}$. Thus, the overall prevalence of pediatric cranial meningioma has not changed in over 50 years.

Clear Cell Meningioma (CCM) is an uncommon histological variant. It has been classified by World Health Organization (WHO) as a Grade II neoplasm. These tumors behave more aggressively than Grade I meningiomas, independently of their location and degree of excision. Most CCMs involve the spine and posterior fossa and the supratentorial location is relatively uncommon ${ }^{11,19,54}$. CCMs involving the supratentorial area in children are extremely uncommon and to the best of our knowledge, only 5 such cases have been reported in the literature till date ${ }^{19,21,29,31,54}$.

In this report, we present a case of a CCM in the temporal base with posterior extension in dumbbell shape in a child. Apart from this case, the authors presented a literature review.

\section{Material and Methods}

We conducted a systematic review based on the methodology outlined in the PRISMA (Preferred Reporting Project for Systematic Evaluation and Meta-Analysis) agreement. This study does not required ethical approval and patient consent.

Our literature search was based on PubMed and LILACS. We used various combinations of the following keywords: "clear cell meningiomas", "meningiomas grade II" and "meningiomas in children", "intracranial meninigomas" and "spine meningiomas". We included clinical trials, comparative studies, observational studies, case reports and other systematical reviews. Only studies in humans and in English were selected for analysis. Studies in children and in adults were included. The evaluation period was from 1990 to 2021 . The latest update was in May, 2020.

The selection criteria focused on design, reporting standards, clarity of results, and tumor classification. Considering the small number of papers found, we decided to also include case reports in our review.

In order to avoid human interference, the analysis was conducted independently. All authors have selected articles for comprehensive screening. The final selected articles have been read and approved by all authors.

Tumor location, sample size, tumor resection (gross or subtotal), recurrence rate, clinical results and conclusion were the parameters evaluated. Data extraction was performed using Microsoft Excel. Due to the small number of studies and subjects, there was no intention to do a quantitative analysis (meta-analysis).

\section{Results}

Seventeen papers written between 1998 and 2019 were included, totalizing 349 patients. The tumor location, results and conclusion were summarized in Table $1^{13,17,18,23,24,25,26,27}$, $28,31,44,47,50,51,52,53$

Between the 346 patients, 191 were female (55.7\%) and 152 male (44.3\%). The mean age was 35.04 (age range $6-86)$. Recurrence after surgery was found in 147 patients $(43.2 \%)$. All the data results can be found in Table $2^{13,17,18,21-}$ 24,26-28,31,42,44,50-53.

Most studies found that CCMs occur in younger patients, especially pediatric age. Females had a higher incidence than males. CCMs showed a more aggressive behavior and higher rates of recurrence than other types of meningioma. Younger patients had a shorter progression-free survival.

Clinical presentation was atypical, including cranial nerve palsies, headache, vomiting, fevers and seizures.

The location of CMMs varied depending on the case series. The most frequent one was the spine (cervical, thoracic, lumbar or sacral). Other locations were: cerebellopontine angle (CPA), frontal lobe, parietal lobe, petroclival, middle and posterior fossa, basal ganglia, foramen magnum, cerebellar tentorium and convexity region.

Most cases underwent surgical treatment. When a gross tumor resection (GTR) could be achieved, recurrence rates were significantly lower. If a subtotal tumor resection (STR) was done, most authors complemented the treatment in adults with radiotherapy.

Cases with a MIB-1 index $\geq 3 \%$ had a shorter progression-free survival (PFS). Ki-67 index did not affect PFS. SMARCE-1 mutation was found in several cases.

\section{Case report}

Female, 3-year-old with complains of sudden onset of holocranial headache associated with vomiting and ataxic gait. Upon neurological examination, the patient presented paresis of the left lateral rectus muscle, vestibular syndrome on the left side and intracranial hypertension syndrome. Magnetic resonance imaging revealed a contrast enhanced well-defined extra-axial mass lesion in left middle cranial fossa with extension into the posterior fossa and cavernous sinus (Figures 1a,1b and 1c). We opted to remove the mass in two stages: middle fossa approach with anterior petrosectomy and 


\begin{tabular}{|c|c|c|c|c|}
\hline \multicolumn{5}{|c|}{ Table 1. Clear Cell Meningioma: Systematical Review } \\
\hline Author / year & Tumor Location & Patients & Results & Conclusion \\
\hline $\begin{array}{l}\text { Wu, L. et al., } \\
2019^{51}\end{array}$ & $\begin{array}{l}\text { Cervical, thoracic, } \\
\text { thoracolumbar, } \\
\text { I u m b a o or } \\
\text { lumbosacral spine }\end{array}$ & $\begin{array}{l}10 \text { patients } \\
3 \text { male } / 7 \text { females } \\
\text { Mean age: } 25.5\end{array}$ & $\begin{array}{l}\text { GTR was achieved in } 9 \\
\text { patients. STR was achieved } \\
\text { in } 1 \text { patient. Postoperative } \\
\text { follow-up magnetic resonance } \\
\text { imaging showed no recurrence/ } \\
\text { regrowth in the } 9 \text { patients with } \\
\text { total removal and } 1 \text { patient } \\
\text { with subtotal removal during } \\
\text { the mean follow-up periods of } \\
68.4 \text { months and } 56.0 \text { months, } \\
\text { respectively }\end{array}$ & $\begin{array}{l}\text { A good clinical outcome after GTR } \\
\text { can be expected, and the risk of } \\
\text { long-term recurrence is low }\end{array}$ \\
\hline$\underset{2018^{26}}{\text { Li, J. et al. }}$ & $\begin{array}{l}\text { Fronto-parietal- } \\
\mathrm{t} \text { e } \mathrm{m} \mathrm{p} \text { o } \mathrm{r} \\
\mathrm{c} \text { o } \mathrm{n} \text { v } \mathrm{xity} \text {, } \\
\text { petrous ridge and } \\
\text { petroclival, skull } \\
\text { base, posterior } \\
\text { fossa, parasagittal } \\
\text { and falx cerebri, } \\
\text { basal ganglia, } \\
\text { third ventricle and } \\
\text { hypothalamus }\end{array}$ & $\begin{array}{l}24 \text { patients } \\
7 \text { males } / 17 \text { females } \\
\text { Mean age: } 46.7\end{array}$ & $\begin{array}{l}\text { During the average follow-up } \\
\text { of } 61.1 \text { months, four patients } \\
(19.0 \%) \text { suffered from tumor } \\
\text { recurrence } \\
\text { Patients with STR or a MIB-1 } \\
\text { index } \geq 3 \% \text { had significantly } \\
\text { shorter progression-free } \\
\text { survival (PFS) compared to } \\
\text { gross total resection GTR and } \\
\text { MIB- } 1 \text { index }<3 \%\end{array}$ & $\begin{array}{l}\text { CCMs have a predilection to affect } \\
\text { younger patients and have a high } \\
\text { rate of recurrence and metastasis. } \\
\text { Surgery resection is the first } \\
\text { treatment choice. For patients } \\
\text { underwent STR or with MIB- } 1 \\
\text { index } \geq 3 \% \text {, further radiotherapy } \\
\text { is necessary }\end{array}$ \\
\hline $\begin{array}{l}\text { Wang, X.Q. et } \\
\text { al., } 2014^{50}\end{array}$ & $\begin{array}{l}\text { Cerebellopontine } \\
\text { angle (CPA), } \\
\text { spine, anterior } \\
\text { basalis, foramen } \\
\mathrm{m} \text { a g } \mathrm{u} \mathrm{m} \text {, } \\
\text { c e r b e I I a r } \\
\text { convexity, } \\
\text { cerebral ventricle, } \\
\text { pe t r c I i val } \\
\text { and cerebellar } \\
\text { tentorium }\end{array}$ & $\begin{array}{l}23 \text { patients } \\
12 \text { male / } 11 \text { female } \\
\text { Mean age: } 34.6\end{array}$ & $\begin{array}{l}17 \text { patients underwent GTR } \\
\text { and } 5 \text { patients underwent STR. } \\
\text { Eleven patients had recurrence } \\
\text { and } 2 \text { eventually died }\end{array}$ & $\begin{array}{l}\text { CPA was the most affected area } \\
\text { in this series. The extent of initial } \\
\text { surgical resection is the most } \\
\text { important prognostic factor }\end{array}$ \\
\hline$\underset{2009^{31}}{\text { Ma, L. et al., }}$ & $\begin{array}{l}\text { Occipital parietal } \\
\text { Lobe }\end{array}$ & $\begin{array}{l}1 \text { patient } \\
1 \text { male } \\
6 \text { years old }\end{array}$ & $\begin{array}{l}\text { CT showed total resection of } \\
\text { the tumor on the second week } \\
\text { after the operation. There } \\
\text { was no evidence of tumor } \\
\text { recurrence during follow-up }\end{array}$ & $\begin{array}{l}\text { Total resection was related to no } \\
\text { tumor recurrence in the follow-up } \\
\text { period }\end{array}$ \\
\hline $\begin{array}{l}\text { Li, J. et al., } \\
2019^{27}\end{array}$ & $\begin{array}{l}\text { Lumbar, cervical, } \\
\text { s a c r a l a n d } \\
\text { thoracic spine }\end{array}$ & $\begin{array}{l}12 \text { patients } \\
5 \text { male / } 7 \text { female } \\
\text { Mean age: } 28.8\end{array}$ & $\begin{array}{l}\text { The mean age at diagnosis } \\
\text { was significantly younger than } \\
\text { that of patients with spinal } \\
\text { meningiomas ( } 28.813 .4 \text { years } \\
\text { vs. } 54.014 .4 \text { years) } \\
5 \text { patients ( } 41.7 \%) \text { experienced } \\
\text { tumor recurrence. Younger } \\
\text { patients had a significantly } \\
\text { shorter progression-free } \\
\text { survival time than older patients }\end{array}$ & $\begin{array}{l}\text { Spinal CCMs tend to affect } \\
\text { younger patients and have a } \\
\text { high recurrence rate. GTR is } \\
\text { considered the optimal treatment. } \\
\text { Radiotherapy could be considered } \\
\text { for patients who had subtotal } \\
\text { resection or for younger patients, } \\
\text { regardless of the extent of removal }\end{array}$ \\
\hline $\begin{array}{l}\text { Kuzeyli, K. et } \\
\text { al., } 2003^{23}\end{array}$ & $\begin{array}{l}\text { Frontal lobe, } \\
\text { temporal fossa }\end{array}$ & $\begin{array}{l}2 \text { patients } \\
1 \text { male / } 1 \text { female } \\
\text { Mean age: } 51\end{array}$ & $\begin{array}{l}\text { After } 6 \text { months of follow-up, the } \\
\text { first patient is in good condition } \\
\text { and neurological examination } \\
\text { is within normal limits except for } \\
\text { a slight left hemiparesis. A right } \\
\text { frontotemporal craniotomy was } \\
\text { performed on the the second } \\
\text { patient, with subtotal excison of } \\
\text { the mass. He died } 45 \text { days later } \\
\text { due to congestive heart failure }\end{array}$ & $\begin{array}{l}\text { Although the differential diagnosis } \\
\text { of CCM with the other clear cell } \\
\text { tumours of the CNS is possible, } \\
\text { the diagnosis of CCM might be } \\
\text { kept in mind in meningioma cases } \\
\text { and close follow-up is required } \\
\text { due to the high risk of recurrence }\end{array}$ \\
\hline
\end{tabular}




\begin{tabular}{|c|c|c|c|c|}
\hline$\underset{2016^{28}}{\text { Li, P. et al., }}$ & $\begin{array}{l}\text { Lumbosacral } \\
\text { s p i n e , } \\
\text { supratentorial, } \\
\text { C P A o r } \\
\text { petrous apex, } \\
\text { infratentorial }\end{array}$ & $\begin{array}{l}36 \text { patients } \\
13 \text { male / } 23 \text { female } \\
\text { Mean age: } 29.3\end{array}$ & $\begin{array}{l}15 \text { patients suffered from tumor } \\
\text { recurrence. Patients after GTR } \\
\text { had significantly longer PFS } \\
\text { time than those after STR. } \\
\text { Age, gender, postoperative, } \\
\text { radiotherapy, progesterone } \\
\text { receptor staining and Ki-67 } \\
\text { index did not have significant } \\
\text { effects on patients' PFS time }\end{array}$ & $\begin{array}{l}\text { The frequency of spinal CCMs } \\
\text { is higher than intracranial ones. } \\
\text { They should be totally resected } \\
\text { when possible to decrease the } \\
\text { risk of recurrence and prolong } \\
\text { patient's PFS time }\end{array}$ \\
\hline $\begin{array}{l}\text { Epstein, N.E. et } \\
\text { al., } 2005^{13}\end{array}$ & $\begin{array}{l}\text { Spinal canal at } \\
\text { the L3-L4 level }\end{array}$ & $\begin{array}{l}1 \text { patient } \\
1 \text { female } \\
41 \text { years old }\end{array}$ & $\begin{array}{l}\text { GTR was performed in the } \\
\text { intradural lesion. Radiation } \\
\text { and chemotherapy following } \\
\text { surgery was not recommended. } \\
\text { The patient remains disease- } \\
\text { free } 1 \text { year postoperatively }\end{array}$ & $\begin{array}{l}\text { In adults, radiation therapy } \\
\text { following GTR should be reserved } \\
\text { for secondary recurrences }\end{array}$ \\
\hline $\begin{array}{l}\text { Zhang, H. et al., } \\
2017^{53}\end{array}$ & Skull base & $\begin{array}{l}146 \text { patients } \\
73 \text { females / } 73 \\
\text { males } \\
\text { Mean age: } 32\end{array}$ & $\begin{array}{l}67.8 \% \text { patients underwent } \\
\text { GTR and } 32.2 \% \text { underwent } \\
\text { STR. } 50.7 \% \text { patients had tumor } \\
\text { recurrence during the follow- } \\
\text { up. Recurrence-free survival } \\
\text { rates at } 1 \text { and } 5 \text { years after } \\
\text { resection were } 86 \% \text { and } 37 \%\end{array}$ & $\begin{array}{l}\text { CCM behaves differently from } \\
\text { the other types of grade II } \\
\text { meningiomas. GTR should be } \\
\text { the primary goal in the surgical } \\
\text { management of intracranial CCMs }\end{array}$ \\
\hline $\begin{array}{l}\text { Rousselot, C. et } \\
\text { al., } 2010^{47}\end{array}$ & $\begin{array}{l}\text { M e d u I I a ry, } \\
\text { sphenoid wing, } \\
\text { pontocerebellar } \\
\text { a n I e a n d } \\
\text { tentorium }\end{array}$ & $\begin{array}{l}7 \text { patients } \\
5 \text { females / } 2 \text { males } \\
\text { Mean age: } 36\end{array}$ & $\begin{array}{l}\text { Three patients underwent } \\
\text { GTR. Recurrence occurred } \\
\text { in four patients, three of them } \\
\text { died from the disease }\end{array}$ & $\begin{array}{l}\text { CCM course is less favourable } \\
\text { than meningioma WHO grade I, } \\
\text { even in the absence of anaplastic } \\
\text { area, high mitotic activity or } \\
\text { necrosis }\end{array}$ \\
\hline $\begin{array}{l}\text { Ito, T. et al., } \\
1998^{18}\end{array}$ & $\begin{array}{l}\mathrm{C} \text { e } r \text { e b e I I a r } \\
\text { tentorium }\end{array}$ & $\begin{array}{l}1 \text { patient } \\
1 \text { female } \\
67 \text { years old }\end{array}$ & $\begin{array}{l}\text { The occipital transtentorial } \\
\text { approach was used. Some } \\
\text { tumor cells infiltrated into the } \\
\text { cerebellar cortex. Gamma knife } \\
\text { radiosurgery was performed } \\
\text { for regrowing tumor } 6 \text { months } \\
\text { after surgery }\end{array}$ & $\begin{array}{l}\mathrm{CCM} \text { may be clinicopathologically } \\
\text { malignant so careful follow-up will } \\
\text { be necessary }\end{array}$ \\
\hline $\begin{array}{l}\text { Lee, W. et al., } \\
2000^{24}\end{array}$ & $\begin{array}{l}\text { Left parietal } \\
\text { convexity }\end{array}$ & $\begin{array}{l}1 \text { patient } \\
1 \text { male } \\
17 \text { years old }\end{array}$ & $\begin{array}{l}\text { M R imaging showed } \\
\text { leptomeningeal enhancement } \\
\text { that progressed into the entire } \\
\text { subarachnoid space after } \\
\text { surgical resection of the primary } \\
\text { tumor (dural-based mass in } \\
\text { the left parietal convexity). } \\
\text { The patient underwent lumbar } \\
\text { surgery and radiation therapy } \\
\text { to the whole brain }\end{array}$ & $\begin{array}{l}\text { CCMs are related to clinical } \\
\text { aggressiveness despite its benign } \\
\text { histologic nature. Metastasis and } \\
\text { recurrence are frequent. Patients } \\
\text { are younger than those in other } \\
\text { subtypes of meningioma }\end{array}$ \\
\hline $\begin{array}{l}\text { Libert, D.M. \& } \\
\text { Prayson, R.A., } \\
2020^{25}\end{array}$ & $\begin{array}{l}\text { Left cavernous } \\
\text { sinus }\end{array}$ & $\begin{array}{l}1 \text { patient } \\
1 \text { female } \\
8 \text { years old }\end{array}$ & $\begin{array}{l}\text { The tumor was associated with } \\
\text { a novel germline SMARCE1 } \\
\text { mutation and somatic NF1 } \\
\text { and DMD mutations. After } \\
\text { two years, the patient had a } \\
\text { recurrence of the tumor and } \\
\text { underwent a second resection }\end{array}$ & $\begin{array}{l}\text { Evaluation of the pathologic } \\
\text { interaction of SMARCE1 loss } \\
\text { with other somatic mutations may } \\
\text { help define the tumorigenesis and } \\
\text { progression of CCM }\end{array}$ \\
\hline $\begin{array}{l}\text { Prayson, R.A et } \\
\text { al., } 2010^{44}\end{array}$ & $\begin{array}{l}\text { Frontal lobe, } \\
\text { cave r n o s } \\
\text { sinus and CPA/ } \\
\text { posterior fossa }\end{array}$ & $\begin{array}{l}18 \text { patients } \\
9 \text { females / } 9 \text { males } \\
\text { Mean age: } 58.1\end{array}$ & $\begin{array}{l}\text { Seven tumors showed CA9 } \\
\text { immunoreactivity, } 5 \text { tumors } \\
(27.8 \%) \text { CD } 10 \text { staining, and } 0 \\
\text { cases showed RCC staining. } \\
10 \text { patients }(62.5 \%) \text { developed } \\
\text { at least } 1 \text { recurrence requiring } \\
\text { surgical intervention }\end{array}$ & $\begin{array}{l}\text { Meningiomas with at least a } \\
10 \% \text { clear cell component tend } \\
\text { to behave in a more aggressive } \\
\text { fashion with increased risk of } \\
\text { recurrence. Immunohistochemical } \\
\text { staining with antibodies to CA9, } \\
\text { CD10, and RCC are potentially } \\
\text { useful in differentiating CCM from } \\
\text { metastatic renal cell carcinoma }\end{array}$ \\
\hline
\end{tabular}




\begin{tabular}{|c|c|c|c|c|}
\hline $\begin{array}{l}\text { King, J. et al., } \\
2009^{21}\end{array}$ & $\begin{array}{l}\text { Middle and } \\
\text { posterior fossae }\end{array}$ & $\begin{array}{l}1 \text { patient } \\
1 \text { female } \\
11 \text { years old }\end{array}$ & $\begin{array}{l}\text { Post-operative MRI six weeks } \\
\text { after the procedure revealed } \\
\text { gross total resection of tumour, } \\
\text { with residual enhancement in } \\
\text { the trigeminal and abducent } \\
\text { nerves on the left side }\end{array}$ & $\begin{array}{l}\text { Meningiomas arising from cranial } \\
\text { nerves are unusual in the pediatric } \\
\text { population. Performing the tumour } \\
\text { removal from the middle fossa } \\
\text { approach avoids the necessity for } \\
\text { a second craniotomy }\end{array}$ \\
\hline $\begin{array}{l}\text { Zhang, G.J. et } \\
\text { al., } \\
2018^{52}\end{array}$ & $\begin{array}{l}\text { Skull base, } \\
\text { convexity region } \\
\text { and parasagittal } \\
\text { region }\end{array}$ & $\begin{array}{l}56 \text { patients } \\
24 \text { males / } 32 \\
\text { females } \\
\text { Mean age: } 42\end{array}$ & $\begin{array}{l}22 \text { patients }(39.3 \%) \\
\text { experienced recurrence, and } 9 \\
\text { patients }(16.1 \%) \text { died. Thirteen } \\
\text { patients }(23.2 \%) \text { had history of } \\
\text { previous surgery }\end{array}$ & $\begin{array}{l}\text { Patients with larger tumor size } \\
\text { and a history of surgery had wors } \\
\text { outcomes }\end{array}$ \\
\hline $\begin{array}{l}\text { Inoue, T. et al., } \\
2018^{17}\end{array}$ & $\begin{array}{l}\text { L5 level, right and } \\
\text { left CPA }\end{array}$ & $\begin{array}{l}3 \text { patients } \\
2 \text { males / } 1 \text { female } \\
\text { Mean age: } 17,7\end{array}$ & $\begin{array}{l}\text { Sanger sequencing of } \\
\text { lymphocyte DNA of all three } \\
\text { patients revealed heterozygous } \\
\text { mutation on the SMARCE } 1 \\
\text { Exon8c.624_627delTGAG, } \\
\text { p. (Ser208Argfs } 26) \text {. Two } \\
\text { patients underwent GTR, while } \\
\text { the other one STR. There was } \\
\text { no recurrence }\end{array}$ & $\begin{array}{l}\text { Total removal of CCM is possible } \\
\text { with an appropriate approach } \\
\text { and meticulous technique before } \\
\text { the tumor invades the brainstem. } \\
\text { Early detection among families } \\
\text { with a CCM patient is } \\
\text { recom mended. G e n e tic } \\
\text { SMARCE } 1 \text { sc re en ing is } \\
\text { recommended for patients with a } \\
\text { family history of CC M }\end{array}$ \\
\hline
\end{tabular}

CCM: clear cell meningioma; GTR: gross tumor resection; STR: subtotal tumor resection; PFS: progression free survival; CPA: cerebellopontine angle; MRI: magnetic brain imaging; CNS: central nervous system; CT: computed tomography.

retrosigmoid approach.

The patient progressed well during surgery and in the postoperative period. She was discharged from the hospital feeling well and with no neurological deficits. Histopathology was suggestive of clear cell meningioma (CCM) (Figure 3a).

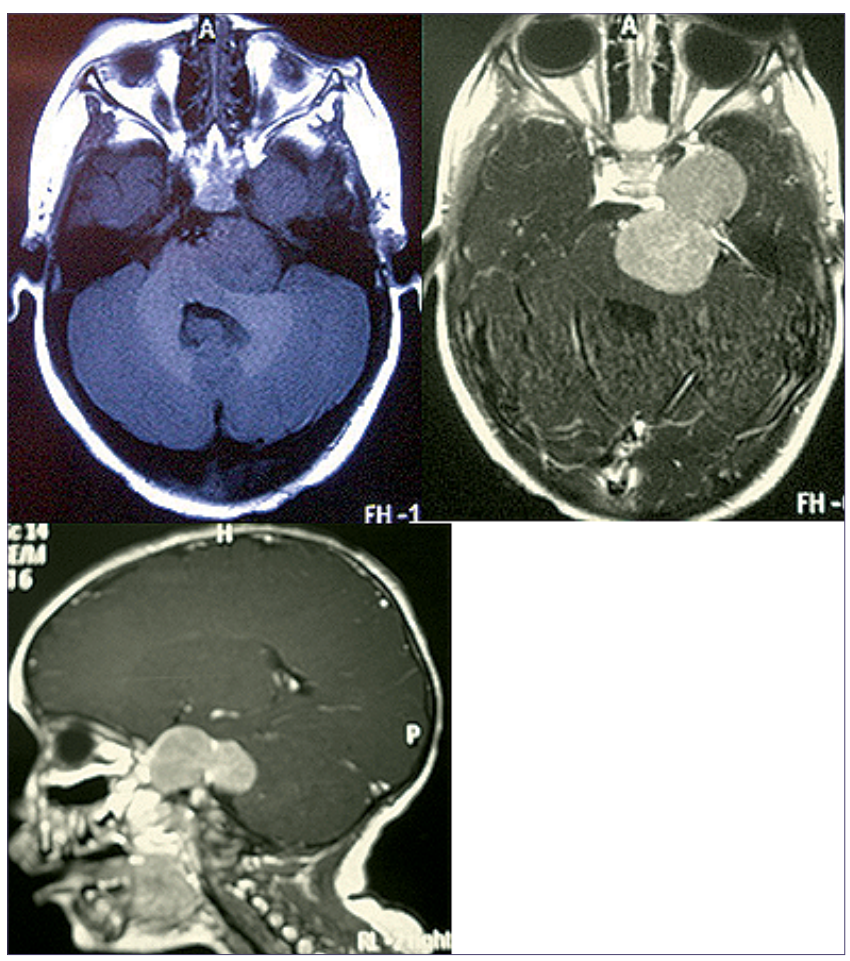

Figure 1. Magnetic Resonance Imaging: T1 axial section a) and sagittal section; b) T1 contrast enhanced axial section; c) showing a well-defined extra-axial mass lesion in right middle cranial fossa with extension into the infratemporal fossa.
Tumor cells were positive for vimentin, S-100 and focally positive for epithelial membrane antigen. The proliferation index measured by means of MIB-1 was $13 \%$ suggestive of aggressive variant.

After 1 month, she was again submitted to surgery. A new approach was performed to remove the residual tumor in the petroclival area. The postoperative MRI showed total resection.

Two weeks later the patient developed subarachnoid hemorrhage due to a pseudoaneurysm bleeding of the basilar trunk. An emergency surgery with clipping to control the hemorrhage was necessary. After the episode, she developed hemiplegia, lesion of left ocular motor nerve and impairment of swallow. She developed hypertonia and spasticity, the verbal contact was also extremely difficult. Three years later, a very small local recurrence was treated by radiosurgery of dural extension.

\section{Discussion}

\section{Epidemiology}

Pediatric meningiomas account for $1.52 \%$ of total meningiomas (15/983) according to large series of Hui et al. ${ }^{16}$. The mentioned author showed that the mean age at presentation was 12 years, with male to female ratio of 1.5:1.

Zorludemir et al. ${ }^{54}$, first described clear cell meningiomas in 1995 and since then < 50 cases have been reported. It was subsequently listed as a distinct entity in the current WHO classification of brain tumors in 2000 . Most cases were single case reports ${ }^{19,22,43,54}$.

\section{Pediatric CCM}

CCM is reported to occur more frequently in the pediatric age group ${ }^{19,24,35}$. Most patients of CCM are young, usually in 


\begin{tabular}{|c|c|c|c|c|c|c|c|c|}
\hline \multirow{3}{*}{ Article } & \multicolumn{8}{|c|}{ Table 2. Clear Cell Meningioma Systematical Review - DATA } \\
\hline & \multicolumn{3}{|c|}{ Patients } & \multirow{2}{*}{$\begin{array}{l}\text { Mean age } \\
\text { (years old) }\end{array}$} & \multicolumn{2}{|c|}{ Tumor resection } & \multirow{2}{*}{$\begin{array}{l}\text { Recurrence } \\
(\mathrm{n} / \%)\end{array}$} & \multirow[t]{2}{*}{ Observation } \\
\hline & Total & Female & Male & & GTR & STR & & \\
\hline $\begin{array}{l}\text { Wu, L. et al., } \\
2019^{51}\end{array}$ & 10 & 7 & 3 & 25.5 & 9 & 1 & $0 / 0 \%$ & - \\
\hline $\begin{array}{l}\mathrm{Li}, \mathrm{J} \text {. et al., } \\
2018^{26}\end{array}$ & 24 & 17 & 7 & 46.7 & 19 & 5 & $4 / 16.7 \%$ & - \\
\hline $\begin{array}{l}\text { Wang, X.-Q. et } \\
\text { al., 201450 }\end{array}$ & 23 & 11 & 7 & 36.4 & 17 & 5 & $11 / 47.8 \%$ & $\begin{array}{l}\text { Two patients } \\
\text { died. The } \\
\text { surgical results } \\
\text { of the remaining } \\
\text { patient were } \\
\text { unknown }\end{array}$ \\
\hline $\begin{array}{l}\text { Ma, L. et al., } \\
2009^{31}\end{array}$ & 1 & - & 1 & 6 & 1 & - & $0 \%$ & - \\
\hline $\begin{array}{l}\mathrm{Li}, \mathrm{J} \text {. et al., } \\
2019^{27}\end{array}$ & 12 & 5 & 7 & 28.8 & 9 & 3 & $5 / 38,45 \%$ & - \\
\hline $\begin{array}{l}\text { Kuzeyli, K. et } \\
\text { al., } 2003^{23}\end{array}$ & 2 & 1 & 1 & 51 & 1 & 1 & $0 / 0 \%$ & $\begin{array}{l}\text { Male patient } \\
\text { died } 45 \text { days } \\
\text { later due to } \\
\text { congestive } \\
\text { heart failure }\end{array}$ \\
\hline $\begin{array}{l}\mathrm{Li}, \mathrm{P} \text {. et al., } \\
2016^{28}\end{array}$ & 36 & 13 & 23 & 29.3 & 24 & 12 & $15 / 41.7 \%$ & - \\
\hline $\begin{array}{l}\text { Epstein, N.E. et } \\
\text { al., } 2005^{13}\end{array}$ & 1 & 1 & - & 41 & 1 & - & $0 / 0 \%$ & - \\
\hline $\begin{array}{l}\text { Zhang, H. et al., } \\
2017^{53}\end{array}$ & 146 & 73 & 73 & 32 & 99 & 47 & $74 / 50.7 \%$ & - \\
\hline $\begin{array}{l}\text { Rousselot, C. et } \\
\text { al., } 2010^{47}\end{array}$ & 7 & 5 & 2 & 36.1 & 3 & 4 & $4 / 57.1 \%$ & - \\
\hline $\begin{array}{l}\text { Ito, T. et al., } \\
1998^{18}\end{array}$ & 1 & 1 & - & 67 & - & 1 & $1 / 100 \%$ & - \\
\hline $\begin{array}{l}\text { Lee, W. et al., } \\
2000^{24}\end{array}$ & 1 & - & 1 & 17 & 1 & - & $1 / 100 \%$ & - \\
\hline $\begin{array}{l}\text { Libert, D.M.; } \\
\text { Prayson, R.A., } \\
2020^{25}\end{array}$ & 1 & 1 & - & 8 & - & 1 & $1 / 100 \%$ & - \\
\hline $\begin{array}{l}\text { Prayson, R.A. et } \\
\text { al. } 2010^{44}\end{array}$ & 18 & 9 & 9 & 58.1 & 10 & 8 & $9 / 56.25 \%(9 / 16)$ & $\begin{array}{l}2 \text { patients left } \\
\text { the study }\end{array}$ \\
\hline $\begin{array}{l}\text { King, J. et al., } \\
2009^{21}\end{array}$ & 1 & 1 & - & 11 & 1 & - & Unknow & - \\
\hline $\begin{array}{l}\text { Zhang, G.J. et } \\
\text { al., } 2018^{52}\end{array}$ & 56 & 32 & 24 & $\begin{array}{l}42 \text { (male } \\
\text { only) }\end{array}$ & 31 & 25 & $22 / 39.3 \%$ & $\begin{array}{l}\text { Nine patients } \\
\text { died }\end{array}$ \\
\hline $\begin{array}{l}\text { Inoue, } T \text {. et al., } \\
2018^{17}\end{array}$ & 3 & 2 & 1 & 17.7 & 2 & 1 & $0 / 0 \%$ & - \\
\hline
\end{tabular}

the first three decades of life, although occasional cases in older patients have also been reported $d^{1,2,3,14,49}$. A slight female predominance has been noted ${ }^{3,4,14,37-42}$. These tumors may recur, spread locally, and even metastasize despite their rather innocuous histological appearance ${ }^{19,24,35}$. Our patient was a 3-year-old girl and the tumor was located in middle cranial fossa with cavernous sinus as well as posterior fossa extension.

Usual sites of occurrence are the spinal canal (intradural, $48 \%$ ), the cerebellopontine angle, tentorium, skull base and 


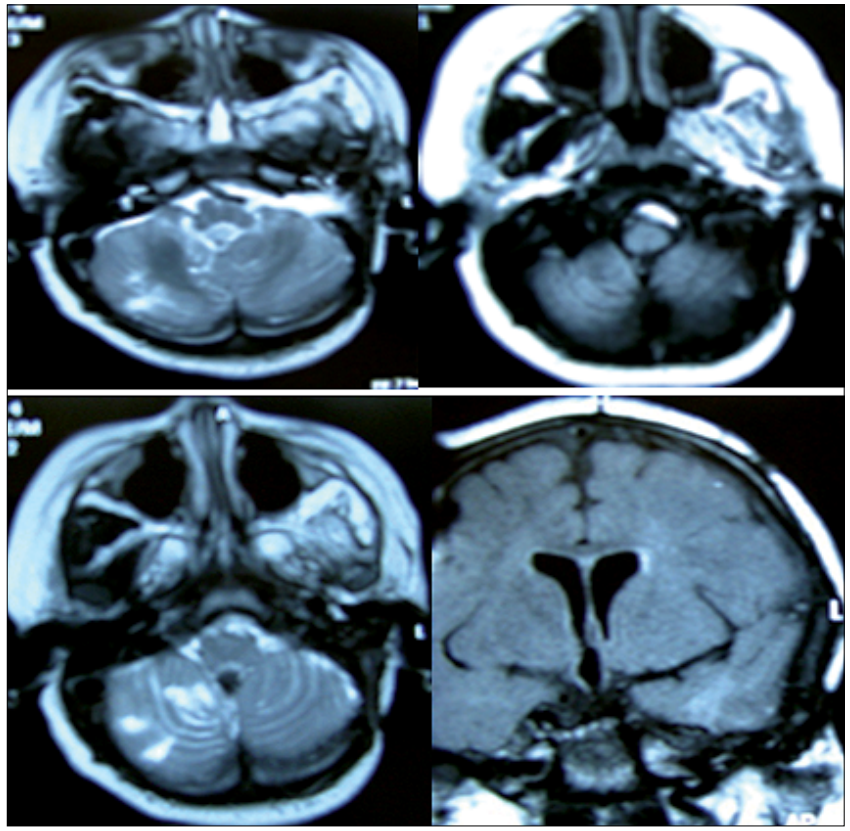

Figure 2. Postoperative contrast enhanced magnetic resonance imaging, a) T2 axial brain imaging; b) T1 axial contrast enhanced brain imaging; c) flair and d) $\mathrm{T} 1$ coronal showing complete excision of tumor.

foramen magnum ${ }^{9,20,24}$. The supratentorial location in pediatric $\mathrm{CCM}$ is rare. Only 6 cases of supratentorial pediatric CCM have been reported till date ${ }^{19,21,31,54}$. In a review of 35 cases of intracranial CCM, Ma et al. ${ }^{31}$, reported only two pediatric patients with supratentorial intraparenchymal CCM. They treated those patients with intracranial and spinal irradiation after surgical removal.

Pereira et al reported a pediatric series with a case of clear cell meningioma ${ }^{37,41}$ and Oviedo et al., 2005 described a 7-year-old boy with a CCM of the cauda equine. Another author published a paper about CCM in the fourth ventricle of 14 year old patient ${ }^{8}$.

\section{Differential Diagnosis}

Prior to the acceptance of CCM as a distinct variant of meningioma, differential diagnosis of tumors with clear cell morphology were often reported as metastatic renal cell carcinoma, oligodendroglioma, hemangioblastoma, and clear cell ependymoma, without specific immunohistochermical
(IHC) analysis. Diagnoses was based solely on histomorphology ${ }^{19,35,54}$. It is known that the absence of IHC facility during the initial pathological analysis, compounded with the lack of sufficient data pertaining to CCM possibly attributed to misinterpretation of initial tumor as an oligodendroglioma ${ }^{11}$. Tumor localization (axial or extra axial) can help the pathologist in this differential diagnosis.

\section{Molecular Biology}

The biological behavior of CCM may be inordinately aggressive, despite its benign histological appearance. It may also display inconsistent correlation with MIB-1 proliferation. Aspects of cell proliferation in CCM and its correlation with edema have been described before. Previous studies noticed that grade of edema and MIB-1 could be associated to malignancy and radiological tumor shape $1,2,15,32,36,48$. Zorludemir et al. ${ }^{54}$, noticed that high MIB-1 tumors (range: 3.3-25.7\%, mean $13.3 \%$ ) had a $61 \%$ recurrence rate, while Jain et al. noticed a $22 \%$ recurrence rate in low MIB-1 tumors ${ }^{19}$.

Zorludemir et al. ${ }^{54}$, in their series found a recurrence rate of $61 \%$, but failed to note any definite correlation between tumor recurrence and mitotic activity, proliferating cell nuclear antigen proliferation indices, percent S-phase determination, or DNA ploidy status. Pimentel et al. ${ }^{43}$, found that recurrent CCMs generally were in the intracranial location and had been treated with subtotal resection.

Now a days, molecular genetics and karyotypic studies have also found consistent correlation between meningioma recurrence and loss of heterozygosis $22 q, 1 p$, and $14 q$, also presence of cyclin $\mathrm{E}^{30,42}$.

Navalkele et al. reported a case of a 6 year-old girl and her 25 year-old mother harboring CCMs. The first one with MRI showing an enhancing tumor infiltrating the prepontine area, extending to cerebellopontine angle along the bainstem and middle fossa, similarly to our case, and the second one with multiple CCMs. Tumor cytogenetics of the child revealed 2 chromosome aberrations, a $95 \mathrm{Mb}$ gain on 13q12.11-q34 and a $62 \mathrm{Mb}$ gain on 20p13-q13.33, and 3 areas of absence of heterozygosis on chromosomes 5 and 17, encompassing the TERT and NF1 genes (including region for SMARCE 1 gene). Neurofibromatosis (NF) type 1 was ruled out clinically. Germline testing excluded NF type 2 and SMARCB1 was found in the mother analysis, but Germline testing excluded NF type 2 and SMARCB1. Germline SMARCE 1 testing revealed a pathogenic variant (c.525delT) in both ${ }^{34}$.

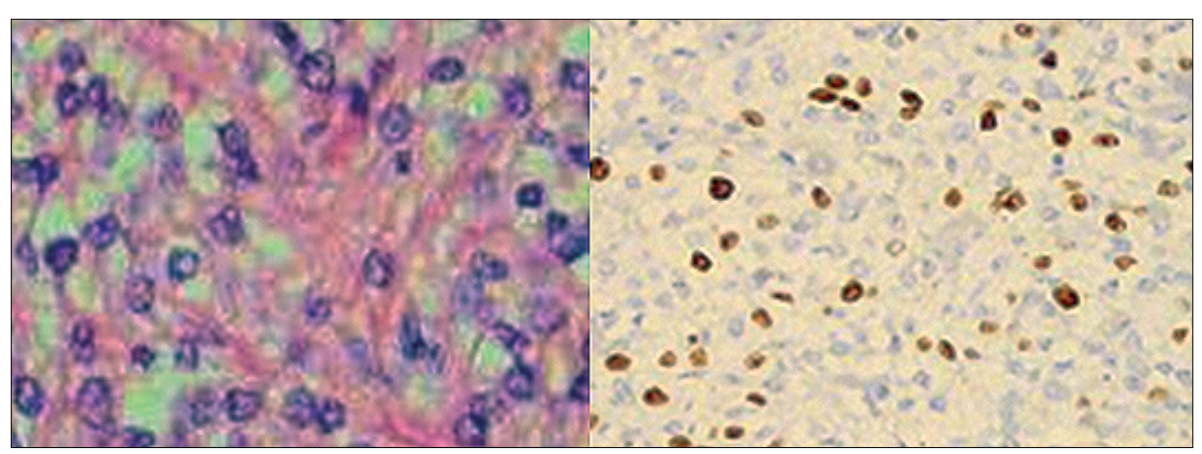

Figure 3. Hematoxylin and Eosin stained sections showing tumor arising from meninges a) Cells displaying round to polygonal cells, central round nucleus, dispersed nuclear chromatin, inconspicuous nucleoli and moderate amount of clear cytoplasm $(\times 400)$; b) Stained proliferation nucleai by means of MIB-1 of $13 \%$. 


\section{Treatment}

The gold standart treatment of CCM is surgery. Radiosurgery and radiotherapy (radiosurgery or stereotatic fraccioned radiotherapy) should be reserved for residual/recurrent cases $^{9,20}$. Staged excision could be an option for children, considering the extensive nature of the procedure in large tumors like in our patient.

Possible complications are CSF leak, venous lesion, arterial lesion $3,4,5,12,45,49$. Small tumors have a higher chance of total resection and smaller complication rates can be observed ${ }^{46}$. Our patient presented a late complication in the postoperative period, a severe subarachnoid bleeding after a rupture of pseudoaneurysm in the basilar artery.

We shall mention that radiotherapy in children can produce neurocognitive complications and late malignancies. In our opinion we must remove residual or recurrent tumors whenever possible, leaving the modalities of irradiation for when excision is not feasible. Irradiated cases shall be followed closely in order to detect malignant transformation after radiotherapy.

\section{Conclusion}

CCMs in childhood are indeed rare. They represent meningiomas with a high grade of recurrence, even when the satisfactory resection of the lesion is accomplished. Recurrence usually appears after subtotal resection. Its similarity to other neoplasias with clear cell aspect (clear cell renal carcinoma) makes the diagnosis sometimes a challenge. The goal of treatment is surgery with total resection of the tumor. In cases of relapse or in cases of residual tumor, it is necessary to use radio-therapeutic devices such as radiosurgery and stereotatic fraccioned radiotherapy. A long-term follow-up is mandatory to truly decipher the natural course of disease in these patients.

\section{Conflict of Interests}

The authors have no conflict of interests to declare.

\section{References}

1. Aguiar, P. H., Agner, C., Simm, R., Freitas, A. B., Tsanaclis, A. M., \& Plese, J. p53 protein expression in meningiomas - a clinicopathologic study of 55 patients. Neurosurgical Review. v. 25, n. 4., p. 252-257, 2002. DOI: 10.1007/s10143-002-0204-2.

2. Aguiar, P. H., Tsanaclis, A. M., Tella, O. I., \& Plese, J. P. Proliferation rate of intracranial meningiomas as defined by the monoclonal antibody MIB-1: correlation with peritumoural edema and other clinicoradiological and histological characteristics. Neurosurgical Review. v. 26, n. 3, p. 221-228, 2003. DOI: 10.1007/ s10143-003-0261-1.

3. Aguiar, P. H. P. de, Tahara, A., Almeida, A. N., Simm, R., Silva, A. N. da, Maldaun, M. V. C., Silva, P. G. Olfactory groove meningiomas: approaches and complications. Journal of Clinical Neuroscience. v. 16, n. 9, p. 1168-1173, 2009. DOI: 10.1016/j. jocn.2008.12.013.

4. Aguiar, P. H. Tahara A, de Almeida AN, Kurisu K. Microsurgical treatment of tentorial meningiomas: report of 30 patients.
Surgical Neurology International. v. 1, n. 36, 2010. DOI: 10.4103/2152-7806.66851.

5. Aguiar, P. H. Aires R, Maldaun MV, Tahara A, de Souza Filho $A M$, Zicarelli CA, Ramina $R$. Is sagittal sinus resection in falcine meningiomas a factor of bad surgical outcome?. Surgical Neurology International. v. 25, n. 64, 2010. DOI: 10.4103/21527806.71983.

6. Almeida, A. N., Pereira BJA, Pires Aguiar PH, Paiva WS, Cabrera HN, da Silva CC, Teixeira MJ, Marie SKN. Clinical outcome, tumor recurrence, and causes of death: a long-term follow-up of surgically treated meningiomas. World Neurosurgery. v. 102, p. 139-143, 2017. DOI: 10.1016/j.wneu.2017.03.009.

7. Amirjamshid, A.; Mehrazin, M.; Abbassioun, K. Meningiomas of the central nervous system occurring below the age of 17: report of 24 cases not associated with neurofibromatosis and review of literature. Childs Nervous System. v. 16, n. 7, p. 406-416, 2000. DOI: $10.1007 / \mathrm{s} 003819900205$.

8. Burgan, O. T. Bahl A, Critcher V, Zaki HS, McMullan PJ, Sinha $S$. Clear cell meningioma of the fourth ventricle: in a child a case report and literature review. Pediatric Neurosurgery. v. 46, n. 6 , p. 462-465, 2010. DOI: 10.1159/000325072.

9. Colen, C. B., Rayes M, McClendon J Jr, Rabah R, Ham SD. Pediatric spinal clear cell meningioma. Case report. Journal of Neurosurgery Pediatrics. v. 3, n. 1, p. 57-60, 2009. DOI: 10.3171/2008.10.17668.

10. Cushing, H.; Eisenhardt, L. Meningiomas: their classification, regional behaviour, life history and surgical end results. Springfield: Charles C. Thomas, 1938.

11. Deb, P.; Datta, S. G. An unusual case of clear cell meningioma. Journal of Cancer Research and Therapeutics. v. 5, p. 324-327, 2009. DOI: 10.4103/0973-1482.59902.

12. de Tella Ol Jr, de Paiva Neto M.A, Aguiar P.H, Herculano M.A. Anterior and lateral foramen magnum meningiomas. Arquivos de Neuropsiquiatria. São Paulo, v. 64, n. 2B, p. 437-40, 2006. DOI: 10.1590/S0004-282X2006000300016.

13. Epstein N. E., Drexler S., Schneider J. Clear cell meningioma of the cauda equina in an adult: case report and literature review. Journal of Spinal Disorders \& Techniques. v. 18, n. 6, p. 539543, 2005. DOI: 10.1097/01.bsd.0000173314.9840.b5.

14. Figueiredo E.G, Aguiar P.H, Córdoba B.F, Fujimoto Y, Rotta J.M, Marino Júnior R. Supratentorial meningiomas. Diagnosis, surgical results and complications. Arquivos de Neuropsiquiatria. São Paulo, v. 56, n. 3A, p. 429-435, 1998. DOI: 10.1590/S0004282X1998000300012.

15. Gasparetto, E. L. Leite Cda C, Lucato L.T, Barros C.V, Marie S.K, Santana P, Aguiar P.H., Rosemberg S. Intracranial meningiomas: magnetic resonance imaging findings in 78 cases. Arquivos de Neuropsiquiatria. São Paulo, v. 65, n. 3A, p. 610614, 2007. DOI: 10.1590/S0004-282X2007000400012.

16. Hui M., Uppin M.S., Saradhi M.V., Sahu B.P., Purohit A.K, Sundaram C. Pediatric meningiomas an aggressive subset: a clinicopathological and immunohistochemical study. Journal of Postgraduated Medicine. v. 61, n. 1, p. 32-35, 2015. DOI: 10.4103/0022-3859.147035.

17. Inoue, T. Shitara S., Ozeki M., Nozawa A., Fukao T., Fukushima $\mathrm{T}$. Hereditary clear cell meningiomas in a single family: threecases report. Acta Neurochirurgica. Wien, v. 160, n. 12, p. 23212322, 2018. DOI: 10.1007/s00701-018-3727-1.

18. Ito T., Nakamura H., Oka K., Nakagawara J., Nagashima K. A case of clear cell meningioma originating from the cerebellar 
tentorium. No Shinkei Geka. v. 26, n. 3, p. 265-270, 1998. PMID: 9558660.

19. Jain, D. Sharma M.C., Sarkar C., Suri V., Garg A., Singh M., Sharma B.S., Mahapatra A.K. Clear cell meningioma, an uncommon variant of meningioma: a clinicopathologic study of nine cases. Journal of Neuro-Oncology. v.81, n. 3, p. 315-321, 2007. DOI: $10.007 / \mathrm{s} 11060-006-9237-7$.

20. Jallo, G. I. Kothbauer K.F., Silvera V.M, Epstein F.J. Intraspinal clear cell meningioma: diagnosis and management: report of two cases. Neurosurgery. v. 48, n. 1, p. 218-221, 2001. DOI: 10.1097/00006123-200101000-00042.

21. King J., Cusimano M., Hawkins C., Dirks P. Extradural middle fossa approach to a clear cell meningioma in a child. Canadian Journal of Neurological Sciences. v. 36, n. 2, p. 257-261, 2009. DOI: $10.1017 / \mathrm{s} 0317167100120311$.

22. Kumar, R., Das K.K., Jaiswal A.K., Mehrotra A., Sahu RN., Srivastava A.K., Jaiswal S., Behari S. Clear cell meningioma in a child: a case report and a review of literature. Asian Journal of Neurosurgery. v. 10 , n. 1 , p. 53, 2015. DOI: 10.4103/17935482.151520.

23. Kuzeyli, K., Cakir E., Usul H., Karaarslan G., Kadir Reis A., Temiz C., Baykal S. Clear cell meningioma: case report and literature review. Journal of Clinical Neuroscience. v. 10, n. 2, p. 264-266, 2003. DOI: 10.1016/s0967-5868(02)00287-4.

24. Lee, W. Chang K.H., Choe G., Chi J.G., Chung C.K., Kim I.H., Han M.H., Park S.W., Shin S.J., Koh Y.H. MR imaging features of clear-cell meningioma with diffuse leptomeningeal seeding. American Journal of Neuroradiology. v. 21, n. 1, p. 130-132, 2000. PMID: 10669237.

25. Libert, D. M.; Prayson, R. A. Pediatric clear cell meningioma involving the middle cranial fossa in the context of NF2 and SMARCE1 mutations. Annals of Diagnostic Pathology, 46, 151516, 2020. DOI: 10.1016/j.anndiagpath.2020.151516.

26. Li, J., Deng, X., Zhang, S., Wang, Q., Cheng, J., Li, X.,Hui, X. (2018). Intracranial clear cell meningioma: Clinical study with long-term follow-up in 24 patients. Clinical Neurology and Neurosurgery, 175, 74-83. doi:10.1016/j.clineuro.2018.10.014

27. Li J, Zhang S, Wang Q, Cheng J, Deng X, Wang Y, Hui X.Spinal Clear Cell Meningioma: Clinical Study with Long-Term Follow-Up in 12 Patients. World Neurosurg. 2019 Feb; 122:e415-e426. doi: 10.1016/ j.wneu.2018.10.064.

28. Li P, Yang Z, Wang Z, Zhou Q, Li S, Wang X, Wang B, Zhao F, Liu $P$. Clinical features of clear cell meningioma: a retrospective study of 36 cases among 10,529 patients in a single institution. Acta Neurochir (Wien). 2016 Jan; 158(1):67-76. PMID: 26573513

29. Li Z, Zhang Y, Wang E, Wang Z, Li W, Huang S. Intracranial clear cell meningioma in two children with blood relations: Two case reports and literature review. Childs Nerv Syst. 2012;28:2143-51.

30. Louis D.N., Scheithauer B.W., Budka H. World Health Organization Classification of Tumors. In: Kleihues P, Cavenee WK, editors. Pathology and Genetics of Tumors of the Nervous System. Lyon: International Agency for Research on Cancer (IARC) Press; 2000. pp. 176-84.

31. Ma L., Liu W.K., Wang K., Shrestha B., Zhang Y.K. Intracranial clear-cell meningioma. Acta Neurochir (Wien) 2009;151:373-8.

32. Mattei T.A., Mattei J.A., Ramina R, Aguiar P.H., Plese J.P., Marino R Jr. Edema and malignancy in meningiomas. Clinics (Sao Paulo). 2005 Jun;60(3):201-6. Epub 2005 Jun 13. PubMed
PMID: 15962080.

33. Miura FK, Cekic O, Moriuchi S, Aguiar PH. Meningioma model. J Neurosurg. 2000 Jul;93(1):162-3. PubMed PMID: 10883933.

34. Navalkele $P$, Guzman M, Pintz H, Kirby A, Geller T, Abduralf $S$. Familial pediatric clear cell with Germline SMARCE 1 mutation. NeurO-oncology 2018; suppl 2:i39.

35. Oviedo A, Pang D, Zovickian J, Smith M. Clear cell meningioma: Case report and review of the literature. Pediatr Dev Pathol. 2005;8:386-90.

36. Panagopoulos AT, Lancellotti CL, Veiga JC, de Aguiar PH, Colquhoun A. Expression of cell adhesion proteins and proteins related to angiogenesis and fatty acid metabolism in benign, atypical, and anaplastic meningiomas. J Neurooncol. 2008 Aug;89(1):73-87. doi: 10.1007/s11060-008-9588-3. Epub 2008 Apr17. PubMed PMID: 18418552.

37. Pereira BJA, Nogueira de Almeida A, Pires de Aguiar PH, Paiva WS, Teixeira MJ, Nagahashi Marie SK. Multiple Intracranial Meningiomas: A Case Series and Review of the Literature. World Neurosurg. 2019 Feb;122:e1536-e1541. doi:10.1016/j. wneu.2018.11.097. Epub 2018 Nov 22. Review. PubMed PMID: 30471445.

38. Pereira BJA, de Almeida AN, Paiva WS, de Aguiar PHP, Teixeira MJ, Marie SKN. Natural history of intraventricular meningiomas: systematic review. Neurosurg Rev. 2018 Aug 15. doi: 10.1007/ s10143-018-1019-0. [Epub ahead of print] Review. PubMed PMID: 30112665.

39. Pereira BJA, de Almeida AN, de Aguiar PHP, Paiva WS, Cabrera HN, da Silva CC, Teixeira MJ, Marie SKN. Atypical and Malignant Meningiomas: Neurooncologic Management in a Brazilian cohort. World Neurosurg. 2018 Feb;110:e20-e23. doi: 10.1016/j.wneu.2017.09.172. Epub 2017 Nov 28. PubMed PMID: 29196252.

40. Pereira BJA, Nogueira de Almeida A, Henrique Pires de Aguiar $P$, Silva Paiva W, Jacobsen Teixeira M, Kazue Nagahashi Marie S. Comprehensive analysis of meningioma in the first two decades of life: A systematic review. Neurochirurgie. 2020 Feb;66(1):36-40. doi: 10.1016/j.neuchi.2019.10.007. Epub 2019 Dec 3. Review. PubMed PMID: 31809786.

41. Pereira BJA, Nogueira de Almeida A, Silva Paiva W, Henrique Pires de Aguiar $\mathrm{P}$, Jacobsen Teixeira M, Kazue Nagahashi Marie $\mathrm{S}$. Neuro-oncological features of spinal meningiomas: Systematic review. Neurochirurgie. 2020 Feb;66(1):41-44. doi: 10.1016/j. neuchi.2019.09.027. Epub 2019 Oct 28. Review. PubMed PMID: 31672597.

42. Pereira BJA, Santana Júnior PA, de Almeida AN, Cavalcante SG, de Melo KCM, de Aguiar PHP, Paiva WDS, Oba-Shinjo SM, Marie SKN. Cyclin E1 expression and malignancy in meningiomas. Clin Neurol Neurosurg. 2020 Mar;190:105647. doi: 10.1016/j.clineuro.2019.105647. Epub 2020 Jan 7. PubMed PMID: 31945623.

43. Pimentel J, Fernandes A, Pinto AE, Fonseca I, Moura Nunes JF, Lobo Antunes J. Clear cell meningioma variant and clinical aggressiveness. Clin Neuropathol. 1998;17:141-6.

44. Prayson, R. A., Chamberlain, W. A., \& Angelov, L. Clear Cell Meningioma: A Clinicopathologic Study of 18 Tumors and Examination of the Use of CD10, CA9, and RCC Antibodies to Distinguish Between Clear Cell Meningioma and Metastatic Clear Cell Renal Cell Carcinoma. Applied Immunohistochemistry \& Molecular Morphology, 1. 2010.

45. Ramina R, Neto MC, Fernandes YB, Aguiar PH, de Meneses 
MS, Torres LF. Meningiomas of the jugular foramen. Neurosurg Rev. 2006 Jan;29(1):55-60. Epub 2005 Sep 30. PubMed PMID: 16195869.

46. Ramina R, Neto MC, Fernandes YB, Silva EB, Mattei TA, Aguiar $\mathrm{PH}$. Surgical removal of small petroclival meningiomas. Acta Neurochir (Wien). 2008 May;150(5):431-8; discussion 438-9. doi: 10.1007/s00701-007-1403-y. Epub 2008 Mar 6. PubMed PMID: 18309454.

47. Rousselot C, Francois $\mathrm{P}$, Jan M, Bergemer AM. Report of seven cases of clear- cell meningioma and a literature review. Ann Pathol. 2010 Apr;30(2):73-82. PMID: 20451062.

48. Simis A, Pires de Aguiar PH, Leite CC, Santana PA Jr, Rosemberg S, Teixeira MJ. Peritumoral brain edema in benign meningiomas: correlation with clinical, radiologic, and surgical factors and possible role on recurrence. Surg Neurol. 2008 Nov;70(5):471-7; discussion 477. doi: 10.1016/j. surneu.2008.03.006. Epub 2008 Jun 30. PubMed PMID: 18586307.

49. Tahara A, de Santana PA Jr, Calfat Maldaun MV, Panagopoulos AT, da Silva AN, Zicarelli CA, Pires de Aguiar PH. Petroclival meningiomas: surgical management and common complications. J Clin Neurosci. 2009 May;16(5):655-9. doi: 10.1016/j.jocn.2008.08.011. Epub 2009 Mar 21. PubMed PMID: 19318254.

50. Wang, X.Q., Huang, M.Z., Zhang, H., Sun, F.B., Tao, B.B., Feng, B.H., Li, S.T. (2014). Clear Cell Meningioma. Journal of Computer Assisted Tomography, 38(2), 200-208.

51. Wu, L., Fang, J., Yang, J., Jia, W., \& Xu, Y. (2019). Clinical features and surgical outcomes of spinal clear cell meningioma: An institutional experience. Journal of Clinical Neuroscience. doi:10.1016/j.jocn.2019.08.037.

52. Zhang GJ, Zhang YS, Zhang GB, Yan XJ, Li CB, Zhang LW, Li $\mathrm{D}$, Wu Z, Zhang JT. Prognostic factors, survival, and treatment for intracranial world health organization grade II chordoid meningiomas and clear-cell meningiomas. World Neurosurg. 2018. Sep;117:e57-e66.

53. Zhang $H$, Ma L, Wang YB, Shu C, Kuang W, Huang YA, Dong LQ, Cheng GG. Intracranial Clear Cell Meningiomas: Study on Clinical Features and Predictors of Recurrence. World Neurosurg. 2017 Jan; 97:693-700.e11 PMID: 27744084.

54. Zorludemir S, Scheithauer BW, Hirose T, Van Houten C, Miller G, Meyer FB. Clear cell meningioma. A clinicopathologic study of a potentially aggressive variant of meningioma. Am J Surg Pathol. 1995;19:493-505. 